\title{
mesh 13
}

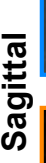

RV RA LA

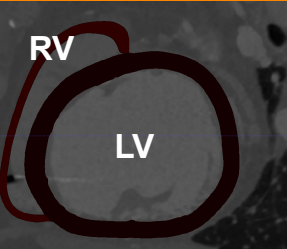

mesh 14

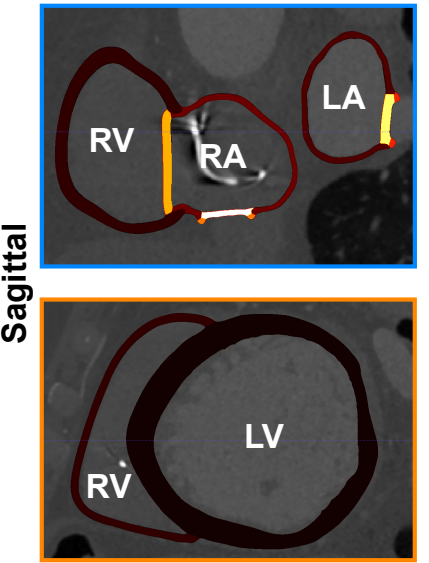

\section{mesh 15}

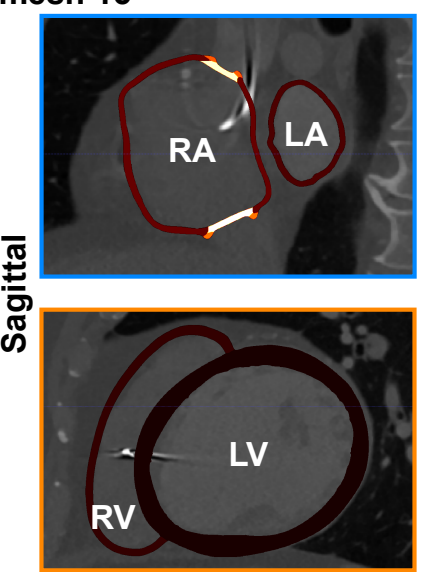

mesh 16

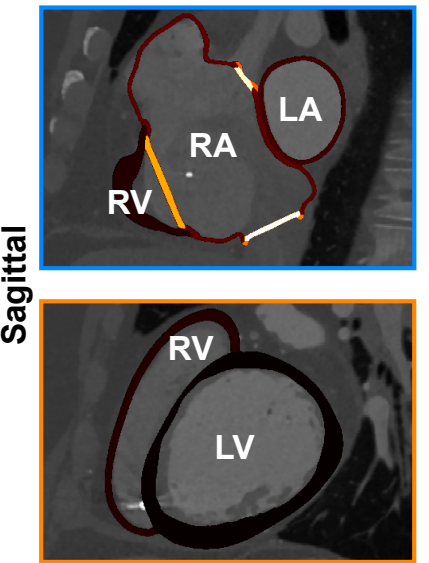

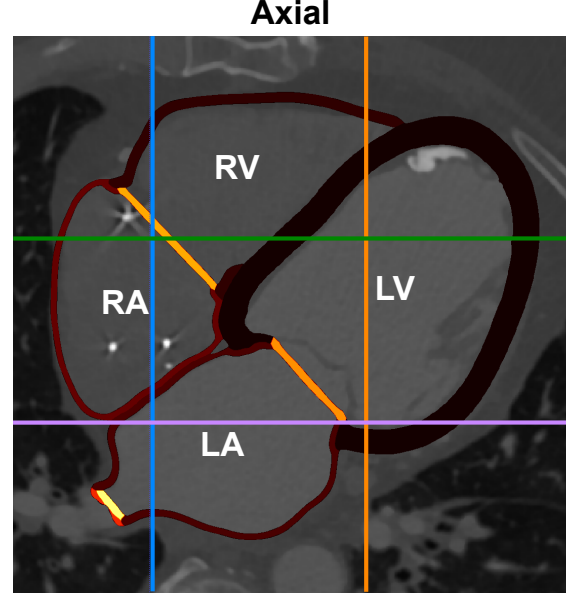
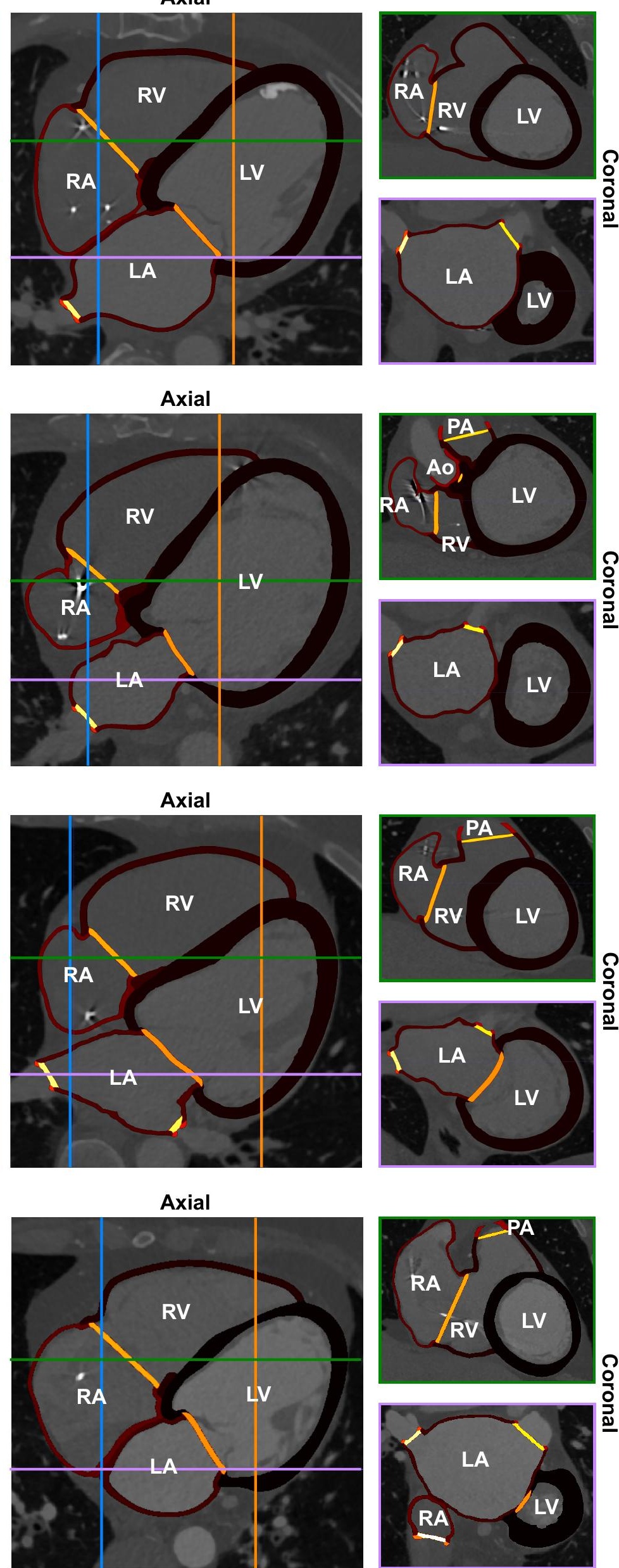